\title{
Politicising women's part-time work in Norway: A longitudinal study of ideas
}

Anne Lise Ellingsæter

University of Oslo, Norway

Ragnhild Steen Jensen

Fafo, the Institute for Labour and Social Research, Norway

\begin{abstract}
Numerous studies have expanded the understanding of part-time work as a gendered labour market phenomenon. However, there has been little research into how societies perceive women's part-time work over time. The passage of several decades since women in great numbers entered the labour market in Scandinavia, many in part-time jobs, provides an opportunity to investigate this. We examine ideas about the nature and desirability of parttime work for women based on government advisory commission reports published in Norway between 1978 and 2016. With the gender contract as a conceptual lens, this longitudinal study of ideas demonstrates how a changing national context transformed perceptions of women's part-time work and the 'woman worker'. From being a strategy for increasing women's economic independence and individual choice, part-time work has become undesirable, whereas full-time work for all women is promoted. The ideational and institutional drivers of the politicisation of women's part-time work are discussed.
\end{abstract}

\section{Keywords}

gender contract, ideas, Norway, part-time work, woman worker

\section{Corresponding author:}

Anne Lise Ellingsæter, Department of Sociology and Human Geography, University of Oslo, PO Box 1096 Blindern, N-0317 Oslo, Norway

E-mail: a.1.ellingsater@sosgeo.uio.no 


\section{Introduction}

Part-time work is associated with women and is commonly seen as a way of helping mothers balance work and family life. However, the role of part-time work in women's adjustment to the labour market differs in extent and form across Europe. There has been a significant growth in part-time work over the past two decades, but it is much less common among women in eastern and southern Europe than in the north-western parts (Sandor, 2011). A contrasting trend is the decline in previously high levels of part-time employment among women in Scandinavia. The link between motherhood and part-time work is also disappearing in these welfare states (Lyonette, 2015).

Both the level of part-time jobs and their quality have been long lasting academic and political issues (e.g. Blossfeld and Hakim, 1997; OECD, 2010; O’Reilly and Fagan, 1998; Nätti, 1995; Warren and Lyonette, 2018). Part-time work often implies job insecurity, career penalties and lower wages and pensions (OECD, 2010). In view of this, part-time work has been subject to policy reform at both national and supra-national levels. In 2000, the EU Part-time Work Directive came into effect, with the main objective being to remove discrimination among part-time workers and promote the flexible organisation of working time (Lyonette, 2015).

Numerous studies have been conducted into various aspects of part-time work, which contribute to the understanding of part-time work as a gendered labour market phenomenon in terms of concepts, causes and consequences. However, the integration of women into the labour market started at different points in time in various countries. The notion of women's part-time work might therefore also entail different things at different points in time. In the Scandinavian welfare states, four to five decades have passed since women entered the labour market in great numbers, many in part-time jobs. Profound structural and cultural transformations have since taken place - in labour markets and social provisions, in family patterns and gender relations. This long passage of time is an opportunity for studying perceptions about women's part-time work under shifting societal contexts. In this case study of Norway, the politicisation of women's part-time work is investigated based on reports from government advisory commissions published between 1978 and 2016: How are ideas about the nature and desirability of part-time work embodied in the questions addressed and the policy solutions proposed? The gender contract is applied as a conceptual lens, and the analysis is structured decade by decade. For each decade, the ideational level of part-time 
work is contextualised by change at the institutional level and in the gender division of labour in families. In the conclusion, we reflect on the ideational and institutional drivers of the politicisation of women's part-time work.

\section{Material}

The empirical analysis is based on ten so-called Official Norwegian Reports (NOU) (for an overview of the reports, see the reference list and table 1). NOUs constitute thorough investigations into an issue or a field of responsibility prepared by a commission appointed by the Government. The commission's work is directed by the mandate given by the Government. It often forms the basis of a report or a proposition from the Government to Parliament. Commissions are appointed to examine and propose solutions to major policy problems. They play a vital role in formulating public policy in Norway and the other Nordic countries and are considered a core element of the consensual Nordic model of government (Christensen and Holst, 2017). Commission members may be bureaucrats, social partners and experts. Over time, particularly from the 1970s to 2000, there was a growing reliance on academic experts and academic knowledge in commission work (Christensen and Holst, 2017).

The criteria for selecting the commission reports were 1) an explicit mandate to investigate some aspect of working time, or 2) working time constituted an important aspect of the problem to be addressed. The reports were analysed chronologically by decade, sorted by the date of the commission's appointment. Key to the analysis was the mandate given to the commission, which formulated the problem to be solved, and the commissions' proposed solutions.

The empirical analysis of changing perceptions of part-time work entails two types of ideas cognitive and normative (Campbell, 1998). Cognitive ideas specify cause-effects, while normative ideas express values and attitudes. Cognitive ideas - or causal ideas - give methods and guidelines for political action. Normative ideas link values to political action and serve to legitimise specific policies and programmes. This study focuses on ideas explicitly articulated and located at the foreground of political debates. However, some ideas may also be taken for granted and reside in the background of policy debates (Campbell 1998). 


\section{The gender contract and the 'woman worker'}

The gender contract is a useful conceptual lens for studying the changing perceptions of women's part-time work (e.g. Fagan and O’Reilly, 1998; Mósesdóttir and Ellingsæter, 2017). Scholars have defined this concept in various ways, for example as setting 'the terms of gender relations in the family and the integration of men and women into the labour market and other social spheres' (Pfau-Effinger, 1993). It has been used to describe the shift away from traditional breadwinner patterns. Esping-Andersen (2009), for example, contends that the upheaval of the old breadwinner order has created a 'social inequilibria' of competing provider models and that a 'new gender contract' based on gender equality is needed. Furthermore, scholars who first introduced the concept used it to study the principles on which the Scandinavian welfare states based their gender relations politics (Gerhard, Knijn and Lewis 2002). Hirdman (1990) analysed the shift from a 'housewife contract' to a 'gender equality contract' in Sweden, focusing on implicit rules with regard to the gender relations underlying institutions, cultural symbols and interaction patterns.

The gender contract is here applied as a contextualised historical concept that denotes the shape of the gender order under historical specific circumstances, as a characteristic of processes in a specific time period (see Hagemann and Åmark, 1999). The gender contract can be identified at an ideational level as a cultural norm/ideal for women and men, which is the focus in this analysis. It can also be viewed at an institutional level in terms of the laws and institutions regulating the gender division of labour, and at an individual level where women and men negotiate the conditions for living together (Hirdman, 1988). Changing gender contracts can thus be seen as changing compromises about the gender division of labour (Gottfried, 2000). A dominant gender contract may appear in some historical periods when all levels reflect the same gender order. However, when analysing change, one must distinguish between processes at different levels; consistency across all levels cannot be assumed a priori (Hagemann and Åmark, 1999). Changes in the gender contract are related to economic and political development, but this is not a simple relationship; women's employment, for example, is not a direct reflection of labour demand (Hirdman 1990).

Conceptions of the 'woman worker' are central to the ideational level of the gender contract. The 'woman worker' emerged as a category and a social problem after the industrial revolution, when motherhood and paid work were established as separate spheres, reflected in 
cultural ideals and institutions underpinning the industrial male breadwinner model (Scott, 1993). The post-war male breadwinner model assumed regular and full-time male employment and stable families in which women would be provided for through their husbands' earnings and social contributions (Lewis 2001). Over the past decades, increasing numbers of women have entered post-industrial labour markets all over Europe. Women's integration in the labour market has caused tensions and growing gender conflicts (Hirdman, 1990). Reconciling work and family is predominantly perceived as a women's conflict, accompanied by perceptions of the 'woman worker' as an encumbered worker, a secondary earner with family obligations. By contrast, men represent the unencumbered 'worker' prototype, free from such obligations (Acker, 1990). Women's part-time work becomes part of a new 'woman worker' compromise. National cultures link women's part-time work to culturally given gender categories (Pfau-Effinger, 1993).

National social provisions and working time regulations influence the conflict between employment and care and the nature of part-time work (e.g. O'Reilly and Fagan, 1998). Some welfare states have attempted to play down the gender conflict (Hirdman, 1990). However, Lewis (2001) has criticised a gender neutral 'adult worker' model taking hold in European social policy: A trend towards the individualisation of social rights and defamilisation of care is neglecting the fact that the necessary care work is still performed by women (see, however, Daly, 2011 for a critical assessment). Lewis' exception is the Scandinavian gender neutral adult worker model, exemplified by Sweden, which recognises care supported by a range of care entitlements with respect to children and older people. Able-bodied adult citizens must engage in paid work in order to qualify for a wide range of benefits based on universal citizenship entitlements. However, they may exit the labour market in order to care. This is supported through programmes such as parental leave with generous wage replacement, including earmarked father quotas, and the provision of formal care services.

\section{0s: Facilitating women's employment and individual choice}

In Norway, demand for labour in the expanding public welfare sector and private services, combined with women entering higher education and more women wanting paid work, heralded the entrance of significant numbers of married women into the labour market. An increase in part-time work accompanied this trend at the beginning (Figure 1 and 2). Parttime work was established as a gendered working time category - men's part-time rates were 
low and changed little throughout the next decades (Kjeldstad and Nymoen, 2012). Social provisions were limited, but change was in the making, initiated by social democracy and the increasing representation of women in parliament. The aim of gender equality was evident in the conversion of paid maternity leave to paid parental leave in 1978. Yet the leave was short, only 18 weeks. Childcare services were scarce and in 1975, only 7 per cent of preschool age children were enrolled (Ellingsæter and Gulbrandsen, 2007). However, in 1976, the Childcare Act laid the foundation for the provision and development of childcare provision as a public responsibility.

\section{FIGURE 1 AND 2 ABOUT HERE}

The issue of how to facilitate women's employment became a key policy issue in this decade. A commission was appointed in 1977 by the minority social democratic government with the mandate 'to consider and propose measures with the aim of stimulating and creating conditions more conducive to more women participating in paid full-time or part-time work' (NOU 1978:7, p. 7). The commission members were ministry bureaucrats. In the Work for women report (NOU 1978:7), economic independence was considered a precondition for accomplishing 'real equality'. But, because of the way society was organised, including insufficient childcare services and traditional gender norms, it would be impossible for many women to work full time - 'for this group of women, part-time work to a large extent satisfies their need for work' (p. 10). Women's particular problems stemmed from their main responsibility for care work. The issue of how to motivate men to take on more care responsibilities was addressed, but women 'cannot wait until men become more involved', and systematic use of part-time work together with other measures such as satisfactory childcare services were proposed (p. 20).

Among the solutions was the creation of more jobs, especially for women, particularly in geographical regions where women had difficulty in finding work. But there was also a normative argument about distributive fairness: women should have a larger share of existing jobs, women should be granted employment according to their wishes and needs to the same degree as men (p. 9, 27). One way of creating more jobs was to share existing jobs by reducing working hours. Part-time arrangements should be facilitated in a wider number of occupations and work places, and conditions for those working part time should be improved. 
A new commission appointed by the same government in 1978 had a broader, gender neutral mandate - to assess the opportunities to 'choose between work and leisure' for all employees who wanted it (p. 7). Commission members were representatives from social partners, ministry bureaucrats and experts. The commission was to propose changes in working time regulations, laws and collective agreements to facilitate individual choice of working time (p. 7). One premise was that workers who wanted reduced working hours should have the same rights as other workers. The Choice of working time report (NOU 1982:52) identified groups with particular needs for reduced working hours (parents of young children, poor health, old age). This commission considered the gender equality effect of better access to part-time work uncertain, as it could weaken women's position in the labour market. However, the majority believed that the overall impact would be positive (p. 12). Women's preference for part-time work was also problematised, as traditional gender roles and a lack of childcare facilities might determine what kind of working time women wanted. However, positive social consequences of reduced working hours included more time for children and other family members, as well as freeing up time for community participation and political participation; the latter was considered a prerequisite for real democracy and contributing to better political decisions. More participants would result in 'a more balanced way of taking into account the different interests in society.' (p.106).

The commission recommended that a higher priority should be given to offering part-time work; companies and workers should be encouraged to share jobs (p. 8). To make individual choice real, conditions that facilitated choice needed to be implemented. A lack of childcare services meant that choices were not real, and the commission proposed an expansion in places and opening hours. The commission majority suggested a legal regulation of the right to reduced hours. However, employer representatives opposed this, fearing that companies would have to provide too many part-time jobs. The majority view succeeded; a regulation added to the Working Environment Act in 1983 (§10) stated that workers with health, social or other significant welfare reasons or needs, have the right to reduced working hours if it does not cause major inconvenience to the company.

In summary: During the 1970s, women's part-time work became perceived as an integral part of a new modified gender contract. Women's care responsibilities made part-time work the preferred option, but it was seen as a temporary, realistic strategy, given the lack of institutional support in terms of childcare services and pervasive ideas about women's 
primary role as carers. Men's working hours were questioned to some extent - achieving a more gender equal distribution of paid work and care work would necessitate a reduction in men's working hours. Expanding individual access to reduced working hours was considered beneficial to all workers and to society.

\section{0s: Working time reductions as welfare policy}

Since the early 1980s, most growth in women's employment occurred in the area of full-time work. While women's part-time working rates dropped, differences between groups of women became more pronounced. Fewer women with a higher education worked in part-time jobs compared with lower educated women. Moreover, in female dominated care and education occupations, part-time work was far more prevalent than in other occupations. Childcare services expanded but were insufficient to cover the increasing demand - in the mid-1980s less than one in three preschool age children had a place (Ellingsæter and Gulbrandsen, 2007). Parents thus had to rely on an expanding private unregulated market for nannies. However, paid parental leave was gradually extended towards the end of the decade.

Part-time work at this point was going through a process of 'normalisation'; social rights and pay were equalised relative to full-time workers. Worker behaviour also 'normalised,' as women in part-time work had similar patterns of employment stability and unionisation as women in full-time employment (Ellingsæter, 1992). These factors were an important premise for the perception of part-time work as the outcome of women's free choice, intertwined with an acknowledged right to choose part-time work.

Working time was a key political issue in the 1980s. In 1985, a commission on working time was appointed by the centre-right government. The mandate was to "submit a broad analysis of the different questions related to various working time reforms such as: shorter working hours, extended access to leave, longer holidays, lower pension age, flexible pension regulation, flexible working time arrangements' (p. 7). The commission was to assess the potential economic effects of alternative working time reforms, as well as the consequences for gender equality, different family types and life stages, and participation in organisations and social life. The commission was not to promote specific proposals but rather indicate future choices to be addressed by labour market policies. Commission members included representatives from the social partners as well as academic experts. 
The Working time reforms report (NOU 1987:9A) was published in 1987 and was accompanied by a large number of commissioned research reports. The commission maintained that the political debate on working time was characterised by increasing disagreement among social groups. While the struggle over working time in the early stages of industrialism was between workers and employers, changes in both working life and family life had generated wider conflicts of interests. The occupational structure had become more differentiated; women constituted a larger share of workers and gender equality had become a more prominent aim. Family patterns had changed, the share of single households was increasing and in families with children both parents were usually employed. 'Changes in gender roles, family life and community life have made working time reforms a question about welfare reform in the broadest sense.' (p. 7).

The increase in part-time work was pointed out as one of the largest changes in the labour market, which did not result from any deliberate political strategy, but rather from married women adapting to a labour market where an eight-hour working day was the norm. The commission report problematised the common assumption that part-time work was an opportunity for greater flexibility for the individual, allowing shifts between full-time and part-time work when the family situation changed (p. 57). There was little research to support this assumption; on the contrary, women who entered the labour market in the 1970s and 1980s to a large extent started and remained in the part-time category (p. 59). Moreover, men with young children did not use part-time work to achieve time flexibility.

The report addressed working time reforms as a gender equality strategy, maintaining that the ongoing debate on gender equality was based on two premises: Women needed economic independence through paid work, and women spent more time than men on unpaid family work and community work (p. 112). The six-hour working day had come 'to represent the most pronounced claim in this context.' (p. 112). This commission was also concerned about the impact on community life if more women entered paid employment. 'A strong increase in the number of employed people deprives local communities of resources', leaving only elderly people and children behind (p. 113). It was difficult to tell how 'good local communities' were created but they 'depend on most people spending some of their time there' (p.114). 
In summary: Working time reforms were addressed as key welfare reforms integrative to labour market policies in the 1980s. A basic tenet was that the transition from an industrial to a post-industrial society generated new temporal needs. Various forms of working time reductions were at the centre of reform thinking; the question was how to prioritise among groups with different temporal needs and interests. Part-time work was considered a problematic gendered adaptation, which did not really reflect the need for flexibility. By contrast, the real individual choice of working time was conveyed as a normative aim with potential welfare gains for all workers, supporting not only a work-family balance but also active citizenship.

\section{0s: Working time flexibility}

This was the decade when 'flexibility' became a contested goal for labour market regulations and 'parental choice' entered the family policy discourse. The trend of increasing employment rates and full-time work among mothers continued. In the mid-1990s, about 80 percent of mothers with preschool aged children were employed. However, less than half of preschool age children were enrolled in childcare and only two in three had a full-time place (Ellingsæter and Gulbrandsen, 2007). Parental leave rights were notably improved; in 1993, paid parental leave increased to 42 weeks with 100 percent compensation. Moreover, fathers were entitled to a 'father quota' - four earmarked weeks on a 'use it or lose it' basis. However, the political right opposed the quota because it limited parental choice. Parental choice also motivated the introduction in 1998 of a cash for childcare benefit for children under the age of three who did not use publicly subsidised childcare services. This benefit was supported by parties on the centre-right of the political spectrum but opposed by left-wing parties. The choice rhetoric in family policies was in stark contrast to the strengthening of the 'work line' in social policies during this decade (incentives for making work pay, emphasising the duty of all able-bodied adults to work), supported across the political spectrum.

Two government commissions with relevance for working time policy were appointed in this decade and they both included representatives from social partners, bureaucrats and academic experts.

One commission was appointed in 1989 by a social democratic minority government, with a mandate to assess whether existing working time regulations could be better adapted to the 
needs of contemporary working life; for companies' to better utilise the means of production and workers' choice of working time. The report, published in 1992, was entitled The good working environment is profitable for all (NOU 1992:20). It concentrated on the regulations of the Working Environment Act of which working time issues constituted a small part. A main perspective was that 'the organisation of working time is of significant importance for the individual worker's family life and social life' and working unsocial hours should be restricted (p.31). The chapter on working time concerned workers' opportunities to choose between different working time arrangements. Few references to the gender of workers were made, and part-time work was addressed to a small extent. The main attention was focused on overtime work and shift work, and the relationship between working hours and health. One question was whether rotating shift schedules (turnus) should be given the right to the same reduced normal working hours as continuous shift arrangements. The commission acknowledged that there were significant health risks for some groups of employees in the healthcare sector working rotation shifts, and that women were overrepresented in these groups. However, no reform was proposed because of 'the great economic strain this would entail for companies.' (p.21).

A centrist minority government appointed the second commission early in 1999. The mandate described challenges for working life arising from the transition from an industrial society to a service and knowledge-based economy, which required new and more flexible ways of organising work. The labour market was also characterised by ever increasing employment rates of women and a growing share of young workers with high educational levels. These groups had other requirements in terms of labour market adaptations and varying needs over the life course. It was not only companies who wanted flexibility; 'workers also want flexibility in the organisation of work' (p.10). The report was submitted at the end of the year and was entitled New millennium - new working life. Security and wealth creation in a flexible working environment (NOU 1999:34). The need for more flexibility in working time arrangements was even more clearly expressed in this report. The choice of working time was seen as gendered - women's dual role with regard to work and family meant that women depended more on working hours and a total workload that made it possible to combine a job and family. This report marked a clear shift compared with previous reports concerning the description and understanding of part-time work. Underemployment among part-time workers - those who want and could work longer hours - was identified as a key issue. Underemployment concerned mostly women -80 percent of those who wanted longer hours 
in 1998 were female. It was argued that this probably was a labour reserve that would be important to activate to avoid future pressures on the labour market (p. 33).

In summary: Citizenship and welfare perspectives waned during the 1990s. There was a notable shift towards labour market flexibility and the individualisation of temporal needs. Towards the end of the decade, women's involuntary part-time work emerged as a new issue. There was a shift from the previous focus on working time reductions to an attention on the organisation of working hours and mobilising of labour reserves. However, women's right to choose part-time work was not an issue.

\section{0s: Involuntary part-time work}

During the 2000s, fathers' caring rights were further strengthened by extensions to the father quota. Fathers with young children spent less time on paid work and more time on childcare, while mothers spent more time in paid work and had significantly cut down on housework in the preceding decades (Kitterød, 2012). Reforms in this decade transformed childcare into a universal system through a huge expansion in places, especially for children under the age of three, and the introduction of maximum parents' fees and parents' right to a place for children aged one to five. There was a significant increase in childcare enrolment. In 2010, nine out of ten children aged between one and five used childcare services, and mthers had become increasingly supportive of childcare services as the best form of care for their children (Ellingsæter et al., 2017). Mothers' employment rates levelled off early in the decade, a likely effect of th introduction of the cash for childcare benefit, but started to grow again in parallel with the expansion in childcare places in the second part of the decade.

Women's part-time work was a key issue in three government commissions in this decade: A commission on underemployment and involuntary part-time work, appointed in 2003 by a centre-right minority government, a commission on equal pay appointed in 2006 by the centre-left government, and a commission on shift/rotation work appointed in 2007 by the same government.

The mandate of the commission on involuntary part-time work was to assess the causes of part-time work, how part-time work influenced employment rates and flexibility in the labour market, and propose measures that could reduce involuntary part-time work. Commission 
members were social partners, ministry bureaucrats and academic experts. The report had the telling title Can more people work more? - Part-time work and underemployment in Norwegian working life (NOU 2004:29). Despite acknowledging the negative consequences of part-time work, many women were not economically independent (p. 65), the commission portrayed it as a positive choice: 'To provide full-time jobs for those who want them is crucial. At the same time, it is not an aim that everyone should work as much as possible. Leisure is also part of welfare. The challenge is to achieve a distribution between work and leisure that best corresponds with the desires of the population.' (p. 42). It was acknowledged that favourable opportunities for working part time probably increased labour market participation. The causes of part-time work were presented as rather complex and involving structural, institutional and individual level explanations. New studies indicated that part-time cultures had evolved and that norms about appropriate working time differed across work places and occupations.

The commission disagreed about the solutions for reducing involuntary part-time work. Representatives of employee federations proposed a legal preferential right of part-time workers to extend their working hours instead of the employer creating a new position. This would advance economic gender equality, and access to full-time work would be a normative marker for women's labour market adaptations (p. 88). Employer representatives contended that a preferential right might provide better income security for women who already had a part-time job and wanted longer hours but may disadvantage the most vulnerable groups of women who have problems getting a job. In 2006, a preferential right for part-time workers was included in the Working Environment Act (§14-3).

The mandate of the commission on shift/rotation work was to investigate the equalisation of working hours among continuous shift workers and rotation shift workers, and to clarify the relationship between part-time work, involuntary part-time work and the organisation of working time. The report was published in 2008 - Shift and rotation work - gradual compensation for unsocial hours (NOU 2008:17). Commission members were mainly academic experts, and one employer and worker representative respectively. In general, it was acknowledged that part-time work was a voluntary adaptation for many and that opportunities for part-time work increased labour market participation, but also that part-time work had problematic effects on gender equality. The normal weekly working hours for continuous shift work, traditionally dominated by men performing industrial work, had been lower than for 
rotation shift work, which was dominated by women in the healthcare sector. Within the healthcare sector, more than half of all women with rotation work worked part-time and underemployment was more frequent among rotation workers. This commission explicitly stated that the part-time preference of some employees generated many other part-time positions, and made other employees work fewer hours than they wanted. Furthermore, parttime work was considered a challenge for demographic trends that were increasing the need for personnel in the healthcare sector - the large group of part-time workers in the sector was considered a labour reserve. A proposed solution for reducing part-time work among rotation workers was a more equal distribution of weekend work.

In the commission report on equal pay Gender and wages (NOU 2008:6), part-time work was considered a key cause of the gender wage gap and involuntary part-time work was a significant problem. Commission members were mainly academic experts, with the social partners in a reference group. The causes of part-time work were complex, generated by individual preferences, norms, gender roles in the family and labour market conditions, including employers' organisation of work. The skewed gender division of labour in the childbearing phase and lack of flexible childcare services were emphasised as areas for improvement. Among the solutions was a more equal sharing of parental leave between parents - it was assumed that 'women's loss of earnings as a consequence of having children will be reduced when men also have to take their share of domestic responsibility' (p. 226).

In summary: In the 2000s, part-time work among women was not only considered a problem for gender equality, but also for the increasing labour demand, particularly in the healthcare sector. Involuntary part-time work was identified as the main problem associated with parttime work. This group of part-time workers constituted a rather limited labour reserve compared with the much larger group of voluntary part-time workers. Nevertheless, women's individual preference for part-time work was not challenged. However, a new perspective entered the discourse: How some women's preferred part-time adaptation meant that other women had to work part-time on an involuntary basis.

\section{From 2010: Full-time work for all women}

There had been a particularly strong increase in mothers' full-time work; in 2016, the parttime working rate among mothers with preschool aged children had dropped to 29 percent 
(Sandvik 2017). Partnered women without children had higher part-time rates. The previously huge gap between demand and supply in childcare services was more or less closed. Women's voluntary part-time work became subject to a contentious public debate; part-time work was challenged as the normal adaptation for women and both employer and employee federations expressed the view that full-time work should also be the norm for women (Mósesdóttir and Ellingsæter, 2017). More full-time working women was promoted as a national asset, a 'goldmine' for Norwegian society according to the PM from the Conservative Party, and one of the objectives of the right-wing government platform in 2018 was to establish a 'full-time culture' in working life.

Two commissions of relevance for part-time work were appointed - one on gender equality, appointed in 2010 by the centre-left government; the other on working time regulations, appointed in 2015 by the right-wing minority government.

The mandate of the gender equality commission was to investigate gender equality policies from a life course, ethnicity and class perspective. The commission members were academic experts. In the Politics for gender equality report (NOU 2012:15), part-time work was addressed in relation to the gender-segregated labour market, work-family adaptations and different working time cultures in various occupations (p. 171). The commission asserted that full-time work was the norm in working life and that some of the problematic aspects of parttime work were related to this norm e.g. income, career development and pension rights. 'Part-time worker' was not only a gendered category, but also related to class and ethnicity. Negative consequences of part-time work were highlighted, and it was maintained that 'parttime work cannot be reduced to a question about the freedom to choose working hours' ( $\mathrm{p}$. 186).

Involuntary part-time work/underemployment particularly affects women with low education and certain female dominated occupations. Women are also less likely to realise their desire to work longer hours than men are. Occupations with a high proportion of voluntary part-time work also had a lot of involuntary part-time work (p.186). The understanding of part-time work as a facilitation of work-family balance was challenged; women work part time at all stages of their life, so caring for young children is far from being the only explanation for women's part time work (p. 187). The commission maintained that the social partners had the 
responsibility for working time agreements. It should be a duty for employers, in cooperation with union representatives, to regularly question the use of part-time positions (p. 187).

The mandate of the commission on working time was to assess the totality of working time regulations and how they were practiced in light of the need to increase labour mobilisation, including the facilitation of full-time work (NOU 2016:1). The mandate stressed that how the total work force is utilised is of the 'utmost importance' to society. High employment levels were prioritised as a political goal and necessary in order to maintain the welfare society and ensure sustainability in the longer term (p. 11). Commission members were academic experts and healthcare bureaucrats, while the social partners participated in a reference group.

The main issue addressed in the report entitled The working time commission (NOU 2016:1), published in 2016, was how to regulate individuals' working time, the relationship between the law and collective agreements and the role of the social partners. The report maintained that, compared with other European countries, employment in Norway was high among female, young and old workers, but working hours were lower than in many other countries. The high employment rate among women suggested that for the vast majority it is possible to combine employment with caring for children. It was stated that while the proportion of parttime work was high among women who entered the labour market in the 1970s, most of the expansion in women's employment after 1980 had been in full-time work. Underemployment and involuntary part-time work were addressed. It was observed that few workers seem to remain underemployed for a long time, and that underemployment was concentrated within sectors where labour demand varies considerably over the day/night and where there is need for continuous operation (p.75). The gender dimension was not brought up in this context. However, when assessing the prevalence of part-time work, it was questioned whether this was a gender, occupational or industrial phenomenon (p. 92). Part-time work varies between industries, and the proportion of part-time work was the highest among both women and men within industries where average working hours were short (e.g. hotels/restaurants, healthcare and social services, personal services and retail). While women worked part time more often than men across all industries, in some industries the share of part-time work among men also was high. Hence, the conclusion was that to some extent part-time work is industry specific. The commission proposed various measures aimed at relaxing working time regulations and providing greater discretion for individual employers/employees. 
In summary: Since 2010, new perspectives on women's part-time work have emerged. Parttime work as a typical work-family adaptation for mothers was questioned, as were individual preferences as a main explanation for women's part-time work. High labour demands in the female dominated care sector were entwined with welfare state sustainability, which made women's voluntary part-time work taking centre stage as a major problem. Choice - workers' opportunities to choose reduced working hours - had disappeared as a normative value.

\section{Conclusion: The end of part-time as a 'universal' of women's work}

Spanning four decades, the commission reports uncover profound changes in the perceptions of the nature and the desirability of women's part-time work (Figure 3). From being a strategy for increasing women's economic independence and individual choice, part-time work has become undesirable, whereas full-time work for all women is promoted. The longterm normative goal of gender equality has merged with the all-encompassing goal of welfare state sustainability. The earlier cognitive perception of part-time work/reduced working hours as a solution to job sharing was replaced by part-time work as a barrier to mobilising the labour needed especially in the female dominated care sector - women' voluntary part-time work was recognised as a labour reserve. Choice weakened as a normative value regarding working time, while citizens' duty to work and economic self-sufficiency increasingly pushed attention towards full-time work. The 'work line' - the goal that everybody must be able to provide for themselves - was not explicitly referred to in the commission reports but figured in the background as a normative consensus. Perceptions of the causes of women's part-time work became more complex - the individual woman's need to reconcile employment and childcare lost traction as the main explanation.

\section{FIGURE 3 ABOUT HERE}

This study demonstrates the advantages of qualitative, longitudinal national case studies in the study of women's work, attending to complexity, context and chronology. It adds insights into how ideational change of the gender contract may interact with change at the other levels of the gender contract, the institutional and the individual level. The gender contract at the ideational level is moving away from the compromise involving a 'normalisation' of women's part-time work as part of a modified male breadwinner contract, towards a new gender neutral adult worker contract. Both institutional reform and a more egalitarian division of labour in 
families have facilitated this shift. However, change in institutions and parents' practices did not occur in tandem with ideational change, but rather preceded and conditioned new ideas about women's part-time work.

The conception of the 'woman worker' was transformed, through a process of degendering. When the 'woman worker' was considered an encumbered worker, part-time work was acknowledged as reconciling women's roles as caregivers and wage workers. However, the institutional context of care work changed fundamentally after the childcare reforms in the 1990s and 2000s - by redistributing care work. Institutional support for fathers' care work changed traditional conceptions of both men and women as parents. The father quota redistributed childcare within the family (although mothers still spend more time caring for children than fathers). Universal childcare provision transferred parts of the care work from the family to the state. Almost all mothers are employed and the majority works full-time. All this changed the basis of the conception of the female worker as a caregiver, facilitating a break with the traditional conception of the 'woman worker' as an encumbered worker. Women and men in principle became (more) equal as workers. This created a new foundation for considering women's employment as not only a right, but as an obligation, as is the case for men. This is likely to have been further strengthened by changes in the general perception of 'the worker' from a democratic citizen who should contribute also to wider society, to a narrower economic actor who should contribute to the national economy and thus the sustainability of the welfare state.

The evolution of the Norwegian variety of the Scandinavian adult worker model has had a somewhat different trajectory than other Scandinavian countries - the level of women's parttime work has been higher and the expansion of publicly subsidised childcare slower, reflecting more ambivalence over working mothers and institutional childcare for young children (Ellingsæter, 2018). However, part-time work in Norway and Scandinavia to a lesser extent has been associated with marginalised forms of work than in many other countries (e.g. Ellingsæter, 1992; Nätti, 1995; Warren and Lyonette, 2018).

In contrast to the Scandinavian adult worker model, the European Union promotes part-time work (Sandor, 2011). The rapid growth of part-time work during the 1980s and early 1990s revealed disadvantages in terms of wages, career advancement and the like, but according to the OECD (2010) this 'clashed with a reality' where the vast majority of women work part- 
time on a voluntary basis. As a result, governments moved away from viewing part-time as a form of 'labour market dualism' and sought to promote it as a way to mobilise groups with traditionally low labour market participation, including mothers with young children. Thus, this perception of women's part-time work still fits the description articulated two decades ago: a 'universal modification' to the existing sexual division of labour, a particular form of gender contract or compromise (Fagan and O’Reilly, 1998).

Considering future prospects of part-time work, Fagan and O'Reilly (1998) suggested demarginalisation and degendering of part-time work for this 'universal' of women's employment to be broken. The present study exposes an alternative pathway: the degendering of full-time work. Economic and demographic conditions shaping the national demand for labour emerge as a driving force in the history of the politicisation of women's work. However, ideas influence framing of policy problems and policy solutions, including ideas with regard to which women and when in their life course they are considered to be workers (Ingold and Etherington, 2013). Mobilisation of labour is a crucial policy concern in contemporary Europe, where policies maximising women's labour force participation are directed at mobilising encumbered women outside the labour market into part-time work. By contrast, the Norwegian case shows that when institutional childcare reforms have eradicated a historical barrier to mothers' employment, women's voluntary part-time work may well emerge as the next reserve to be tapped.

\section{Acknowledgements}

The authors would like to thank the anonymous reviewers and Heidi Nicolaisen for helpful comments.

\section{Funding}

This article is based on research funded by the Research Council of Norway, grant number 237031.

\section{References}

Acker J (1990) Hierarchies, jobs and bodies: A theory of gendered organizations. Gender \& Society 4: 139-158. 
Blossfeld HP and Hakim C (1997) Between equalization and marginalization: women working part-time in Europe. Oxford: Oxford University Press.

Campbell JL (1998) Institutional analysis and the role of ideas in political economy. Theory and Society 27(3): 377-409.

Christensen J and Holst C (2017) Advisory commissions, academic expertise and democratic legitimacy: the case of Norway. Science and Public Policy 1-23, online first.

Daly M (2011) What Adult Worker? A Critical Look at Recent Social Policy Reform in Europe from a Gender and Family Perspective. Social Politics 18(1): 1-23.

Ellingsæter AL (1992) Part-time work in European welfare states. Denmark, Germany, Norway and Denmark compared. Oslo: Institute for Social Research.

Ellingsæter AL (2018) Norway - the evolution of a Nordic earner-carer model. In: Shaver S (ed.) Handbook on Gender and Social Policy. Cheltenham: Edward Elgar, 370-387.

Ellingsæter A L and Gulbrandsen L (2007) Closing the child care gap: The interaction of childcare supply and mothers' agency in Norway. Journal of Social Policy 36: 649-669.

Ellingsæter, A.L., Kitterød, R.H. \& Lyngstad, J. (2017) Universalising Childcare, Changing Mothers' Attitudes: Policy Feedback in Norway. Journal of Social Policy 46: 149-173.

Esping-Andersen G (2009) The Incomplete Revolution. Cambridge: Polity.

Fagan C and O'Reilly J (1998) Conceptualising part-time work: the value of an integral perspective. In O'Reilly J and Fagan C (eds) Part-time Prospects: An international comparison of part-time work in Europe, North America and the Pacific Rim. London: Routledge, 1-31.

Gerhard U, Knijn T and Lewis J (2002) Contractualization. In Hobson B, Lewis J and Siim, B (eds) Contested Concepts in Gender and Social Politics. Cheltenham: Edward Elgar, 105-140. 
Gottfried H (2000) Compromising positions: emergent Neo-fordisms and embedded gender contracts. British Journal of Sociology 51(2): 235-259.

Hagemann G and Åmark K (1999) Fra 'husmorkontrakt' til 'likestillingskontrakt'. Yvonne Hirdmans genusteori. In Engelstad F (ed) Om makt. Teori og kritikk. Oslo: Ad Notam Gyldendal, 174-206.

Hirdman, Y (1988) Genussystemet - reflexioner kring kvinners sociale underordning. Kvinnoventenskaplig tidskrift 19: 49-63.

Hirdman Y (1990) Genussystemet. In SOU 1990:44 Demokrati och makt i Sverige. Stockholm: Almenna Förlaget, 73-116.

Ingold J and Etherington D (2013) Work, welfare and gender inequalities: an analysis of activation strategies for partnered women in the UK, Australia and Denmark. Work, Employment \& Society 27: 621-638.

Kitterød H (2012) Fedre deltar mer i husarbeid og omsorg. Samfunnsspeilet 26: 56-63.

Kjeldstad R and Nymoen EH (2012) Part-time work and gender: Worker versus job explanations. International labour review 151: 85-107.

Lewis J (2001) The Decline of the Male Breadwinner Model: Implications for Work and Care. Social Politics 8(2): 152-169.

Lyonette C (2015) Part-time work, work-life balance and gender equality. Journal of Social Welfare and family Law 37 (3): 321-333.

Mósesdóttir L and Ellingsæter AL (2017) Ideational struggles over women's part-time work in Norway: Destabilizing the gender contract. Economic and Industrial Democracy, online first.

Nätti J (1995) Part-Time Work in the Nordic Countries: a Trap for Women? Labour 9: 343357. 
OECD (2010) Employment Outlook 2010. Paris.

Pfau-Effinger B (1993) Modernisation, culture and part-time employment: The example of Finland and West-Germany. Work, Employment \& Society 7(3): 383-410.

Sandor E (2011) Part-time work in Europe. Luxembourg: Publications Office of the European Union.

Sandvik O (2017) Hvordan deler småbarnsforeldre på arbeidet - ute og hjemme? Samfunnsspeilet 3/2017.

Scott JW (1993) The Woman Worker. In Fraisse G and Perrot M (eds) A History of Women in the West. IV. Emerging Feminisms from Revolution to World War. Cambridge, Mass.: The Belknap Press of Harvard University Press, 399-426.

Warren T and Lyonette C (2018) Good, Bad and Very Bad Part-time Jobs for Women? Reexamining the Importance of Occupational Class for Job Quality since the 'Great Recesssion' in Britain. Work, Employment and Society 32: 747-767.

\section{Government advisory commission reports}

NOU 1978:6 Arbeid for kvinner.

https://www.nb.no/statsmaktene/nb/d9297024bb709583d143ad43e32eblec? index=2\#0

NOU 1980:52 Valg av arbeidstid. Om $\phi k t$ adgang til deltidsarbeid.

https://www.nb.no/statsmaktene/nb/448e0020ab374a44145985c9de47dc59? index=4\#0

NOU 1987:9A Arbeidstidsreformer.

https://www.nb.no/statsmaktene/nb/2060b2d1a688f16621da76cf64422f3c?lang=no\#0

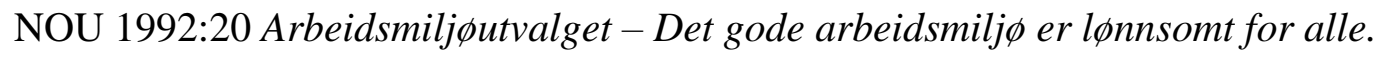

https://www.nb.no/statsmaktene/nb/8af788d6d3068dae5812e1920b2efb7f?index=7\#0 
NOU 1999:34 Arbeidslivsutvalget - Nytt millennium nytt arbeidsliv

https://www.regjeringen.no/nb/dokumenter/nou-1999-34/id142327/

NOU 2004:29 Kan flere jobbe mer https://www.regjeringen.no/nb/dokumenter/nou-2004$\underline{29 / i d 389495 /}$

NOU 2008:17 Skift og turnus - gradvis kompensasjon for ubekvem

arbeidstid https://www.regjeringen.no/nb/dokumenter/nou-2008-17/id528756/

NOU 2008:6 Kjфnn og lфnn https://www.regjeringen.no/nb/dokumenter/nou-2008-

$\underline{6 / \mathrm{id} 501088 /}$

NOU 2012:15 Politikk for likestilling https://www.regjeringen.no/nb/dokumenter/nou-2012$\underline{15 / i d 699800 /}$

NOU 2016:1 Arbeidstidsutvalget https://www.regjeringen.no/no/dokumenter/nou-2016$\underline{1 / \mathrm{id} 2467468 /}$

\section{Author biographies}

Anne Lise Ellingsæter is a Professor of Sociology at the University of Oslo. Her research interests include family policy, gender and work, working time and fertility. She has authored and co-authored a number of articles and books on these topics.

Ragnhild Steen Jensen, PhD, is a researcher at Fafo, Institute for Labour and Social Research. Her research interests include gender equality and work, gender segregation in the labour market and working time.

Figure 1. Employment rates by gender. 1972-2016. Percent. 


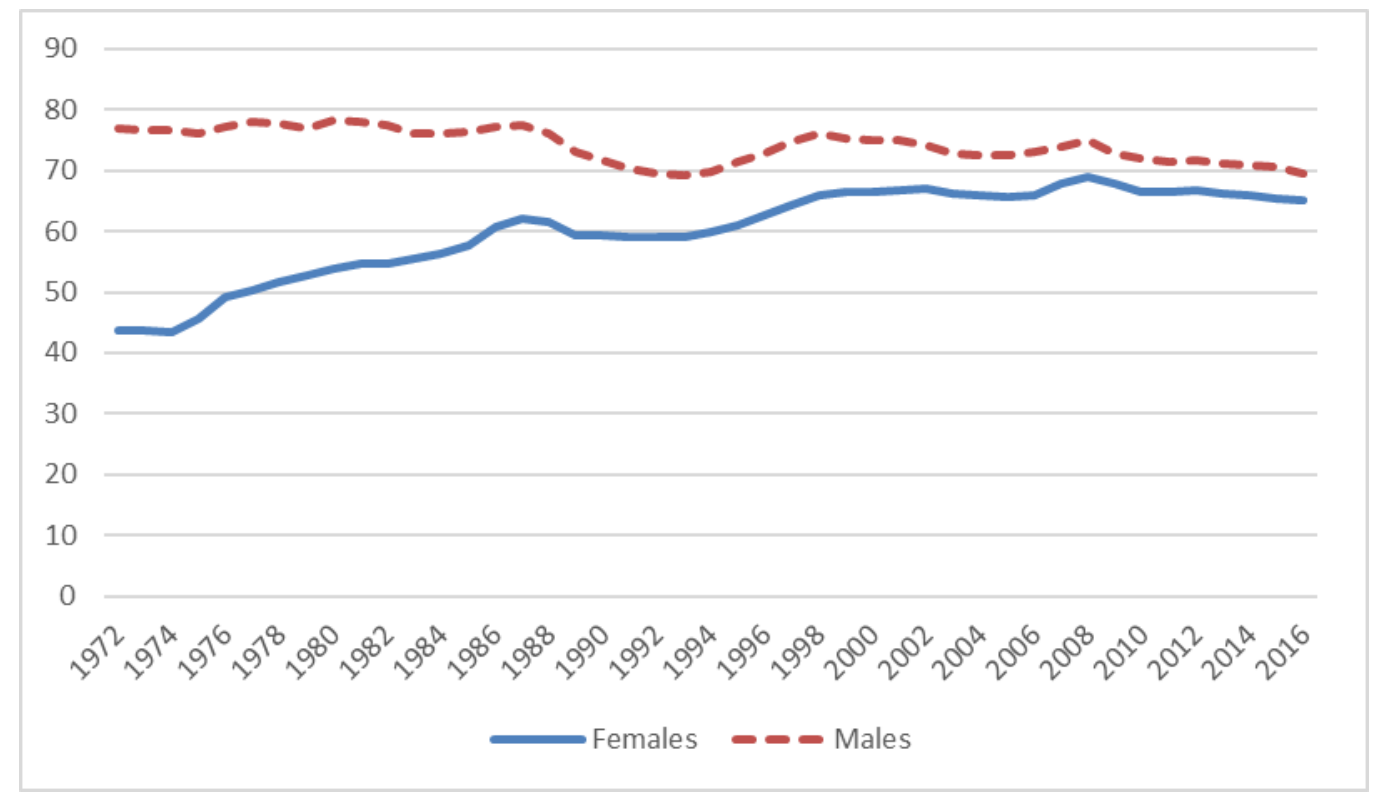

Source: Labour Force Surveys. Persons aged 15-74 years (before 2006: 16-74 years).

Figure 2. Proportion working part-time among employed women and men. 1972-2016.

\section{Percent}

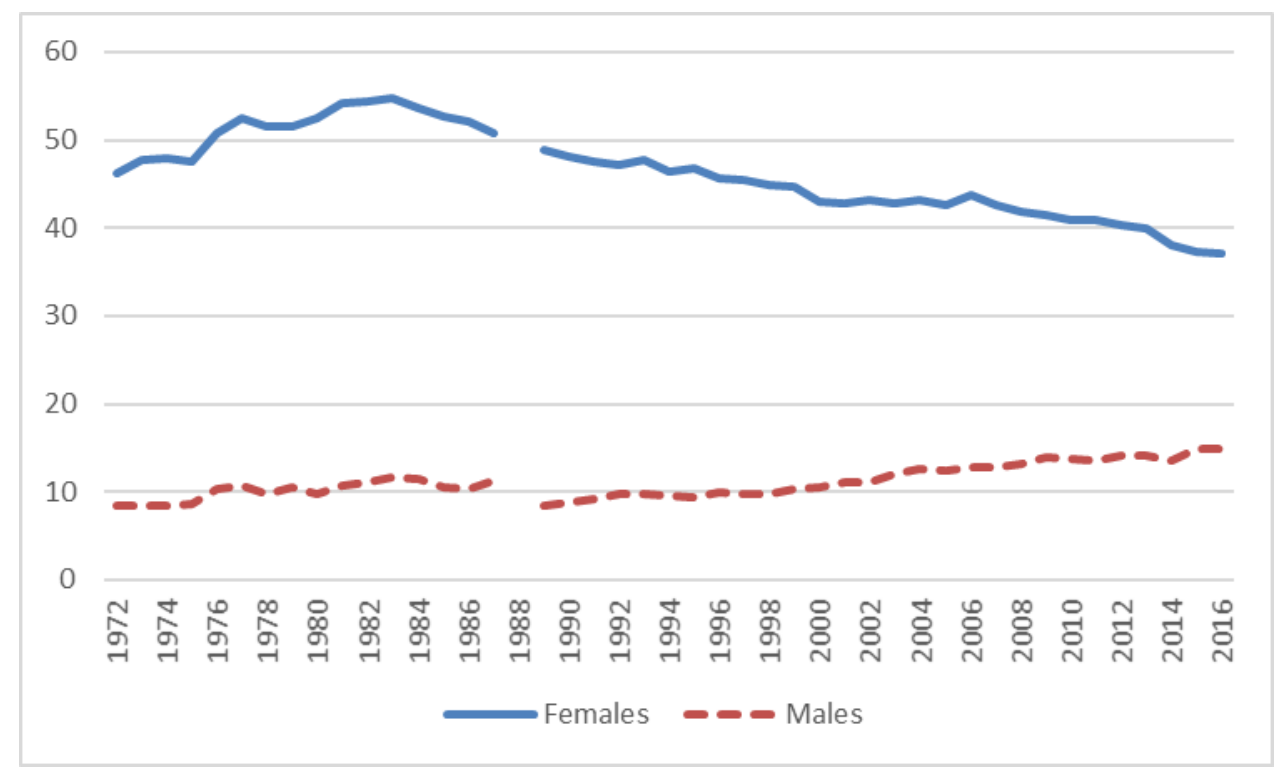

Source: Labour Force Surveys. Persons aged 15-74 years (before 2006: 16-74 years). Parttime:1-36 hours/week, full-time: 37 hours/week or more. 
Figure 3. Main ideas about women's part-time work in reports from advisory commissions 1978-2016.

\begin{tabular}{|c|c|c|}
\hline $\begin{array}{l}\text { Time } \\
\text { period/reports }\end{array}$ & Normative ideas & Cognitive ideas \\
\hline $\begin{array}{l}\text { 1970s } \\
\text { NOU 1978:6 } \\
\text { NOU 1980:52 }\end{array}$ & $\begin{array}{l}\text {-Gender equality } \\
\text {-Women's economic } \\
\text { independence } \\
\text { - Sharing of care } \\
\text { work between } \\
\text { mothers and fathers } \\
\text {-Choice of working } \\
\text { time as welfare } \\
\text {-Participatory } \\
\text { citizenship }\end{array}$ & $\begin{array}{l}\text {-Redistribution of } \\
\text { jobs/job sharing } \\
\text {-Part-time as temporary } \\
\text { solution } \\
\text {-Expansion in childcare } \\
\text { services needed }\end{array}$ \\
\hline $\begin{array}{l}\text { 1980s } \\
\text { NOU 1987:9A }\end{array}$ & $\begin{array}{l}\text {-Women's economic } \\
\text { independence } \\
\text {-Choice of working } \\
\text { time as welfare }\end{array}$ & $\begin{array}{l}\text {-Increase labour market } \\
\text { flexibility } \\
\text {-Prioritise between } \\
\text { conflicting group } \\
\text { interests }\end{array}$ \\
\hline $\begin{array}{l}\text { 1990s } \\
\text { NOU 1992:20 } \\
\text { NOU 1999:34 }\end{array}$ & $\begin{array}{l}\text {-Gender equality } \\
\text {-Individualised } \\
\text { temporal needs }\end{array}$ & $\begin{array}{l}\text {-Increase labour market } \\
\text { flexibility, deregulate } \\
\text { work contracts }\end{array}$ \\
\hline $\begin{array}{l}\text { 2000s } \\
\text { NOU 2004:29 } \\
\text { NOU 2008:6 } \\
\text { NOU 2008:17 }\end{array}$ & $\begin{array}{l}\text {-Gender equality } \\
\text {-Choice of working } \\
\text { time as welfare }\end{array}$ & $\begin{array}{l}\text {-Increase labour supply } \\
\text { (healthcare sector) } \\
\text {-Reduce involuntary } \\
\text { part-time work and } \\
\text { undesirable part-time } \\
\text { cultures } \\
\text {-Counteract career } \\
\text { penalties (pay gap, } \\
\text { pension rights) }\end{array}$ \\
\hline
\end{tabular}




\begin{tabular}{|l|l|l|}
\hline 2010s & -Gender equality & -Reduce negative \\
NOU 2012:15 & -Welfare state & effects of part-time \\
NOU 2016:1 & sustainability & work \\
& & - Mobilise labour \\
& & reserves, women's full- \\
& & time work \\
\hline
\end{tabular}

